INTERNATIONAL JOURNAL OF MULTIDISCIPLINARY RESEARCH AND ANALySis

ISSN(print): 2643-9840, ISSN(online): 2643-9875

Volume 04 Issue 09 September 2021

DOI: 10.47191/ijmra/v4-i9-12, Impact Factor: 6.072

Page No.- $1276-1281$

\title{
The Ground Water Quality Analysis Agro based Industrial Area of Materwadi (Rajaramnagar) Village in Dindori Block, Dist. Nashik of Maharashtra, India
}

\author{
M.D.Wagh ${ }^{1}$, B.C.Kachhava' ${ }^{2}$, S.J.Pawar ${ }^{3}$ \\ ${ }^{1,2}$ Department of Chemistry K.E.S.A.C.S College Kalwan (Manur) Pin-423501 Tal- Kalwan Dist-Nashik (Maharashtra), India. \\ ${ }^{3}$ Department of Zoology K.E.S.A.C.S College Kalwan (Manur) Pin-423501 Tal- Kalwan Dist-Nashik (Maharashtra), India.
}

\begin{abstract}
The ground water analysis has been done during the on season and off season of the sugar industry. The samples collected from 30 sampling stations were analyzed in the laboratory. The analysis reveals that the $\mathrm{pH}, \mathrm{TDS}, \mathrm{DO}, \mathrm{COD}, \mathrm{BOD}$ of water increasing due discharge effluent in the catchments of the sugar industry area. Most of the parameters indicated that these industrial effluents disturb the ground water quality and responsible for deteriorating soil conditions. From the analysis it is reported that there is a requirement of the careful supervision, constant monitoring and periodical analysis of the chemical parameters to safeguard the ground water resources and to minimize environmental pollution nearby the agro-based industries like sugar factory.
\end{abstract}

KEYWORDS: Ground water, Water quality, Environmental pollution.

\section{INTRODUCTION}

Water is important natural asset for human being. The contamination of surface and subsurface water is serious problem among the nations. Various studies have been pointed out that the adjoining areas of the Industries contaminating the ground water resources. The Central Groundwater Board, Nagpur has undertaken specific ground water pollution studies in different parts of Maharashtra to study the impact of natural and manmade activities on the ground water quality. Few cases of groundwater contamination in Beed district due to sugar industry have been recorded. (Machale, 2010) Ground water analysis report near to areas Sangamner Bhag Sahakari Sakhar Karkhana and Mangalam industries located near Sangamner city in Ahmednagar district of Maharashtra has brought out the facts that the damage to the ground water in the areas is due to the percolation of the effluent generated from these industries. The ground water quality around Mangalam industry has also been affected with conductivity ranging between 11000 to $54000 \mathrm{mmhos} \mathrm{cm}-\mathrm{I}$ at $250 \mathrm{C}$ and TDS, 4800-20000 mg/L with very high concentrations of cations and anions. The BOD and COD have gone as high as 450 and $1678 \mathrm{mg} / 1$ respectively. TDS, TH, Ca, Mg, C1 and NO3 content are above maximum permissible limit of BIS for drinking water in $50 \%$ of samples. Thus, this case has proved that the agro base industries are significantly responsible for the contamination of groundwater both biologically and chemically in rural part of Maharashtra by deteriorating the quality of water. (Pondhe, 2005). Various studies have pointed out that disposal of wastewater from industries in open space and abandoned dug wells have thus caused the pollution of groundwater in some rural part (Chaterji et.al., 1964; Vishwnathiah et.al., 1977; Ubale et.al., 2000; Wagh et.al., 2000; Shakhare et.al., 2005; Pondhe, 2005). On this background to analyze the impact of the Kadwa sahakari sugar industry effluent on the adjoining areas of the Materwadi (Rajaramnagar) village in Dindori Block, Dist. Nashik Maharashtra (India) have been selected for the present study.

\section{STUDY REGION}

The Nasik district stretches between Latitude: $19^{\circ} 58^{\prime} 0^{\prime \prime} \mathrm{N}$ (deg min sec), $19.9667^{\circ}$ (decimal), 1958.00N (LORAN) Longitude: $73^{\circ}$ 49' 0" E (deg min sec), 73.8167 (decimal), 07349.00E (LORAN) Elevation: 601 metres (1972 feet) .The Industrial Area of Materwadi (Rajaramnagar) village in Dindori Block, Dist. Nashik Maharashtra (India) has been selected for the present study. 


\section{The Ground Water Quality Analysis Agro based Industrial Area of Materwadi (Rajaramnagar) Village in Dindori}

Block, Dist. Nashik of Maharashtra, India

\section{MATERIALS AND METHODS}

For the purpose of study of groundwater quality of this region, the samples were collected during on and off season from the adjoining areas of the sugar industry. Water samples were collected from different above mentioned places using spot sampling procedure [De, 1988] in previously washed and dried plastic cans. The temperature, $\mathrm{pH}$ and DO of the samples were noted at sampling point itself. The physical and chemical parameters such as Conductivity, Turbidity, TDS, Chloride, TH, Calcium, Magnesium,Sodium, $\mathrm{K}, \mathrm{Cl}-$,SO42-,PO42-,NO3-,,COD,BOD etc. were analyzed using volumetric and spectrophotmetric methods (NEERI 1981, Trivedy and Goel 1986,APHA 1992,. Some of the values obtained from the analysis compared with WHO standards acceptable permissible limits and ICMR Standards acceptable permissible limits. (Please see Table No.1)

\begin{tabular}{|l|l|l|}
\hline \multicolumn{2}{|l|}{ Table :- Water Quality Standards for Drinking } \\
\hline \multicolumn{2}{|l|}{ (Source - Central Board for the prevention and control of water pollution, New Delhi) ${ }^{12}$} \\
\hline Parameters & $\begin{array}{l}\text { WHO standards acceptable } \\
\text { permissible limits }\end{array}$ & $\begin{array}{l}\text { ICMR Standards acceptable permissible } \\
\text { limits }\end{array}$ \\
\hline Turbidity NTU & 5 & 10 \\
\hline $\mathrm{pH}$ & $<8$ & $7-8.5$ \\
\hline Conductivity micromohas/cm & 1500 & 1500 \\
\hline TDS mg/1 & 1000 & 500 \\
\hline Total hardness mg/1 & 300 & 300 \\
\hline Alkalinity mg/l & 200 & 200 \\
\hline Chloride mg/1 & 70 & 75 \\
\hline Calcium mg/l & 250 & 250 \\
\hline Magnesium mg/l & 30 & 50 \\
\hline Nitrate mg/1 & 50 & 45 \\
\hline Sulphate mg/1 & 250 & 150 \\
\hline
\end{tabular}

\section{RESULT AND DISCUSSION}

The variations in analyzed physical and chemical characteristics discussed along with the standard values in as follows.

4.1 pH-pH is the measurement of free acidity or alkalinity of water solution, hence it is an important factor for water analysis. In the present investigation the range of pH of water during October 2009 to March 2010 was found to be in between 7.0 to 7.9 at all 30 sampling station. The maximum pH values were recorded high from December to end of March (In this period Effluent Treatment Plant is functioning) months. $\mathrm{pH}$ is minimum in months of April to September (7.0 to 7.4) which slightly increased in monsoon months. The changes in $\mathrm{pH}$ together with conductivity of water body indicate the presence of certain pollutants. (Pawar et. al. 1985). ( Please see Graph No.1)

4.2 Conductivity: It is ranged from minimum $492 \mu \mathrm{mho} / \mathrm{cm}$ to $3890 \mu \mathrm{mho} / \mathrm{cm}$ maximum, showing large measure of soluble ions which is confirmed by the presence of other metals and chlorides as well as other parameters. The average conductivity is changed in the off season, it ranging from $496 \mu \mathrm{mho} / \mathrm{cm}$ to $3575 \mu \mathrm{mho} / \mathrm{cm}$. The conductivity is remain high due to effluent remain in stagnant condition as well the wells aside to the sugar factory shows high results. (Approximately250 meter away) (Please see graph.3)

4.3 TDS: Total dissolved solids were recorded in the range between 267 to $2558 \mathrm{mg} / \mathrm{l}$ at the various sites during on season. The Values changes slightly in the off season of the factory. The range of these value is 302 to 2323 . The minimum values were recorded during May to October and maximum in November to April months. ( Pls.see Graph No.2)

4.4 DO: The concentration of DO regulates the distribution of flora and fauna. Seasonally the concentration of DO was more during monsoon rainfall. The range is 4.3 to 7.6. The DO values are slightly alkaline during summer i.e.2.6 to 7.1.It is due to Caco3 used in the Pan boiling unit to obtain white color to sugar crystal and to maintain pH of waste water in ETP plant. [Young, Y.G.,. 2008]. 


\section{The Ground Water Quality Analysis Agro based Industrial Area of Materwadi (Rajaramnagar) Village in Dindori Block, Dist. Nashik of Maharashtra, India}

4.5 COD: Chemical oxygen demand is a method to determine the organic load of water body i.e. susceptible to oxidation. COD as a result of pollution is largely determined by the various organic and inorganic materials (Calcium, magnesium, potassium, sodium, etc.). (Raymahashay, B.C., (1986). The level of chemical oxygen demand seems to be the appropriate indices for assessing the pollution level of water bodies (Jakher, 2003). The high COD values are found mainly in water, which may be due to the mixing of domestic and industrial waste (Mariappan,V., 2007). The COD values are ranging from 3.3 to $23 \mathrm{mgl}$ in the on season as well it is pertaining to note that these values are not going to change in the off season. These values were ranging between 7.8 to $25 \mathrm{mgl}$ .The result clearly indicated the prescribed limit of COD is $4 \mathrm{mg} / \mathrm{l}$ as per USPH Standards for drinking water. The $90 \%$ of water samples shows high COD and remaining is below the standard limit. Similar trends were also observed at Raghograh in M.P. (Megha Rai and Shrivastava, 2006). (Graph No.4)

4.6 BOD: The BOD values is ranging between 2.8 to 10.2 in the on season of the sugar factory. These values increasing towards 3.2 to 13.3 winter season. Because of the growth of the micro-fauna in the water.

4.7 Total Hardness: It is the sum of the polyvalent cations present in water. The ions such as calcium and magnesium in combination with bicarbonates, carbonates, sulphide, sulphates and other anions make the water hard. Hard waters are belived to be more productive than soft waters. Hard waters may also create problems to human health causing gastritis (Acosta-Martinez V., T.M. Zobeck, and Vivien Allen (2004).The range of total hardness varied from $83 \mathrm{mg} / \mathrm{l}$ to $510 \mathrm{mg} / \mathrm{l}$ at different sampling stations during on season because of mixing of various types of effluents from distillery and effluent plant. The hardness reduced up-to 84 to $317 \mathrm{mg} / \mathrm{l}$ in the off season. Total hardness was found to maximum in the month of February as $510 \mathrm{mg} / \mathrm{l}$. Hardness of water affects on health of human being. The water with hardness has potential to produce high crop yield. The successful experiments have been recorded by Kranti Sugar factory of the Sangli district (Kranti Sugar Industry Report 2007).

4.8 Chloride: It is one of the most important parameter in assessing the water quality. It is of the opinion that higher concentration of chlorides indicates the higher degree of organic pollution, major components of organic load were TRO, $\mathrm{MgSO}_{4}, \mathrm{H}_{2} \mathrm{SO}_{4}$ etc used in the laboratory. Seasonally, chloride was found to be high during summer season because of cleaning of machinery and low during rainy season (Y.G Young, 2008).Level of chlorides are important in detecting the contamination of ground water by waste water. The chloride content was found to be ranged between $83 \mathrm{mg} / \mathrm{l}$ to $510 \mathrm{mg} / \mathrm{l}$ in on season.

4.9 Sulphate: In the present study the sulphate concentration observed in the range from $18 \mathrm{mg} / \mathrm{lit}$ to $94 \mathrm{mg} / \mathrm{lit}$ during the study period. It fall within the BIS permissible limit of $400 \mathrm{mg} /$ /it.Sulphate if it exceeds the maximum allowable limit than it causes a laxative effect on human system. Sulphate content is found variable in all seasons. This is in the confirmation with results obtained at Jodhpur.

\subsection{Calcium and Magnesium:}

From the hardness values, it has been assumed that carbonates and bicarbonates of calcium and magnesium are the major contents causing hardness which may be due to the natural accumulation of lime by rock soil interaction kinetics or direct pollution by the industrial and domestic waste water. High content of calcium and magnesium ions are significant and which make possible classification of water samples and to assess the soil lithology present in the study area (Mariappan,V.,et al 2005).In the present study the values of calcium ranges from $25 \mathrm{mg} / \mathrm{l}$ to $95 \mathrm{mg} / \mathrm{l}$ at various sampling sites as well the values remains same throughout year. Magnesium ranges from 03 to $24 \mathrm{mg} / \mathrm{l}$. in on season decline towards 3.6 to 13.3 in the off season of the sugar factory.

4.11 Phosphates \&Nitrates- The Values of the Phosphate is 0.11 to 0.66 in all season in the early period of the sugarcane crushing increasing towards 0.12 to 0.85 in the of season. The analysis for the Nitrate is not detected primary investigation but the summer sample shows that 0.01 to 1.03 . Phosphates \&Nitrates responsible for the salinity of the soil in the nearby areas.

4.12 Sodium and Potassium- the Analysis for the Sodium is 46 to $541 \mathrm{ppm}$ increasing towards the 80 to 528 . There is no significant change has been observed in case of sodium. The Potassium value are ranging between 1.5 to 11.03 in the on season. Further in the off season it is ranging between 1.3 to 8.1 which is quite high than permissible limits. 
The Ground Water Quality Analysis Agro based Industrial Area of Materwadi (Rajaramnagar) Village in Dindori Block, Dist. Nashik of Maharashtra, India

Graphs of the Some Chemical Parameters-

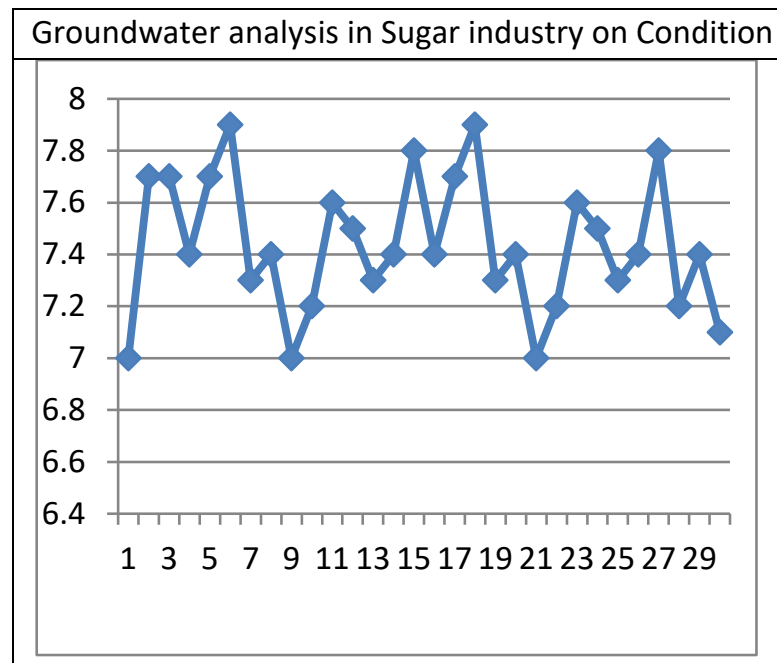

$\mathrm{pH}$ values -7.0 to 7.9 Graph No.1

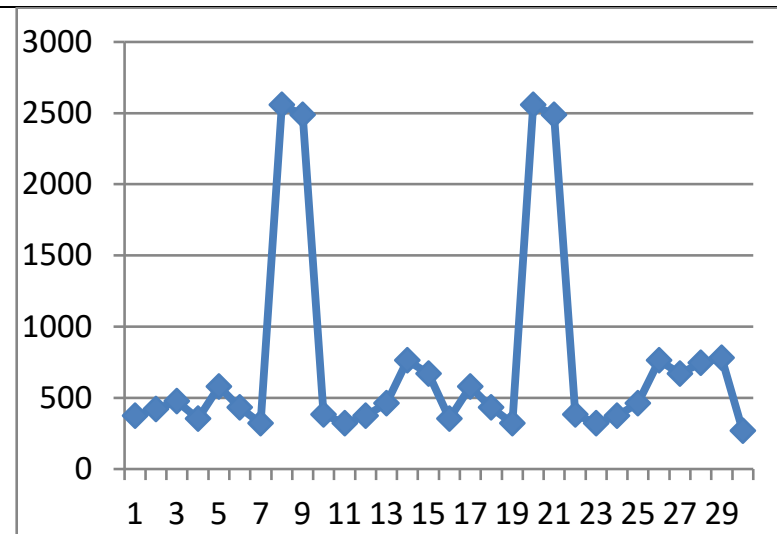

Total Dissolved Solids - 267 to $2558 \mathrm{mg} / \mathrm{l}$ Graph No.2

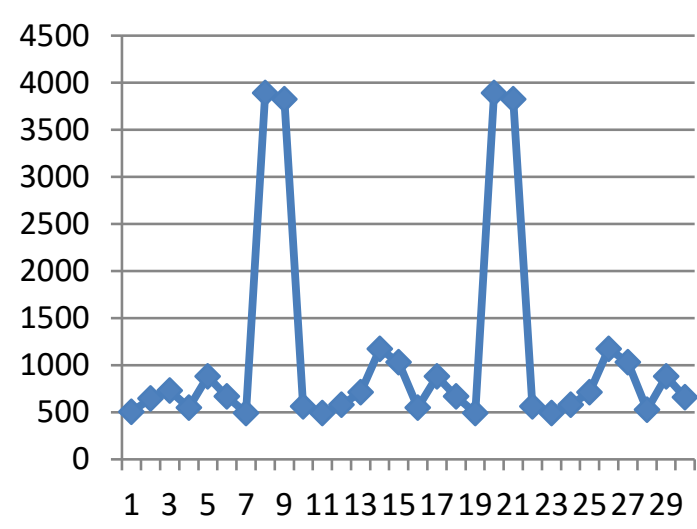

Electrical Conductivity $492 \mu \mathrm{mho} / \mathrm{cm}$ to $3890 \mu \mathrm{mho}$ /cm Graph No.3
Groundwater analysis in Sugar industry off Condition

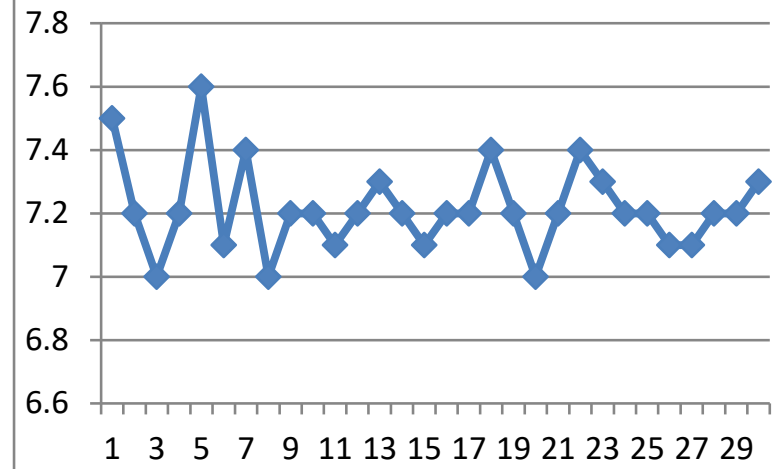

$\mathrm{pH}$ values -7.0 to 7.4 Graph No.1

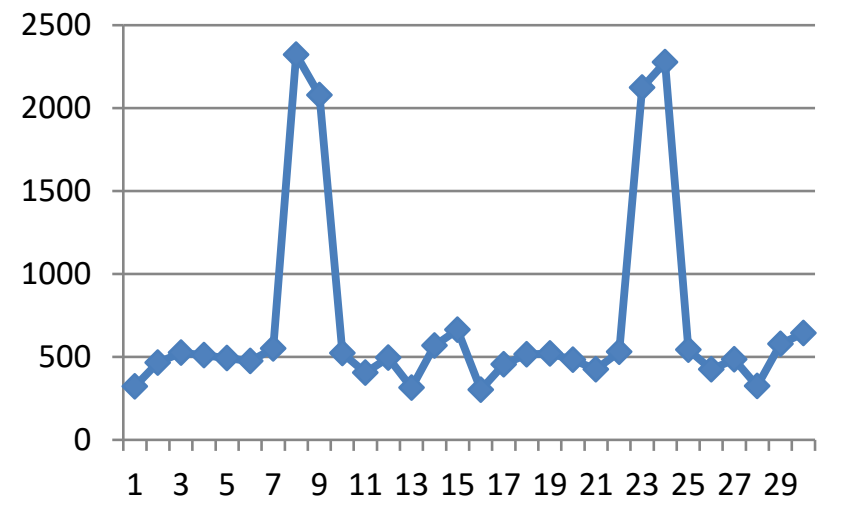

Total Dissolved Solids -302 to $2323 \mathrm{mg} / \mathrm{l}$ Graph No.2

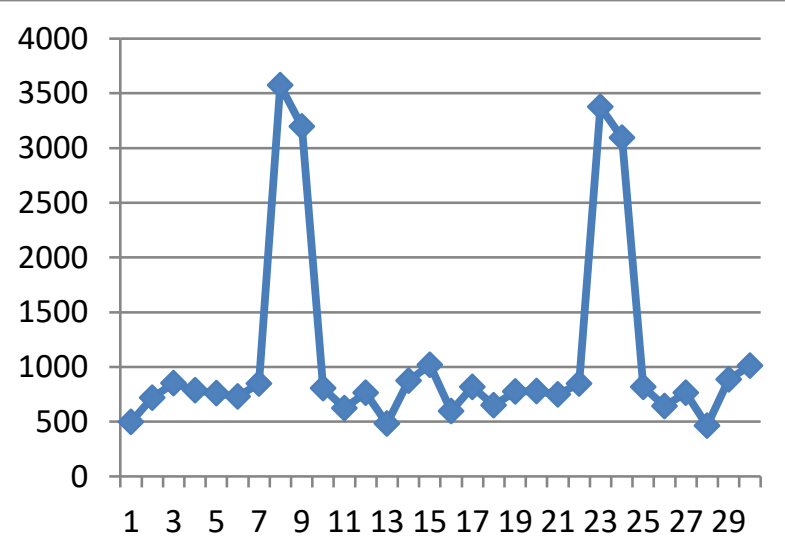

Electrical Conductivity-496 $\mu \mathrm{mho} / \mathrm{cm}$ to $3575 \mu \mathrm{mho} / \mathrm{cm}$ Graph No.3 


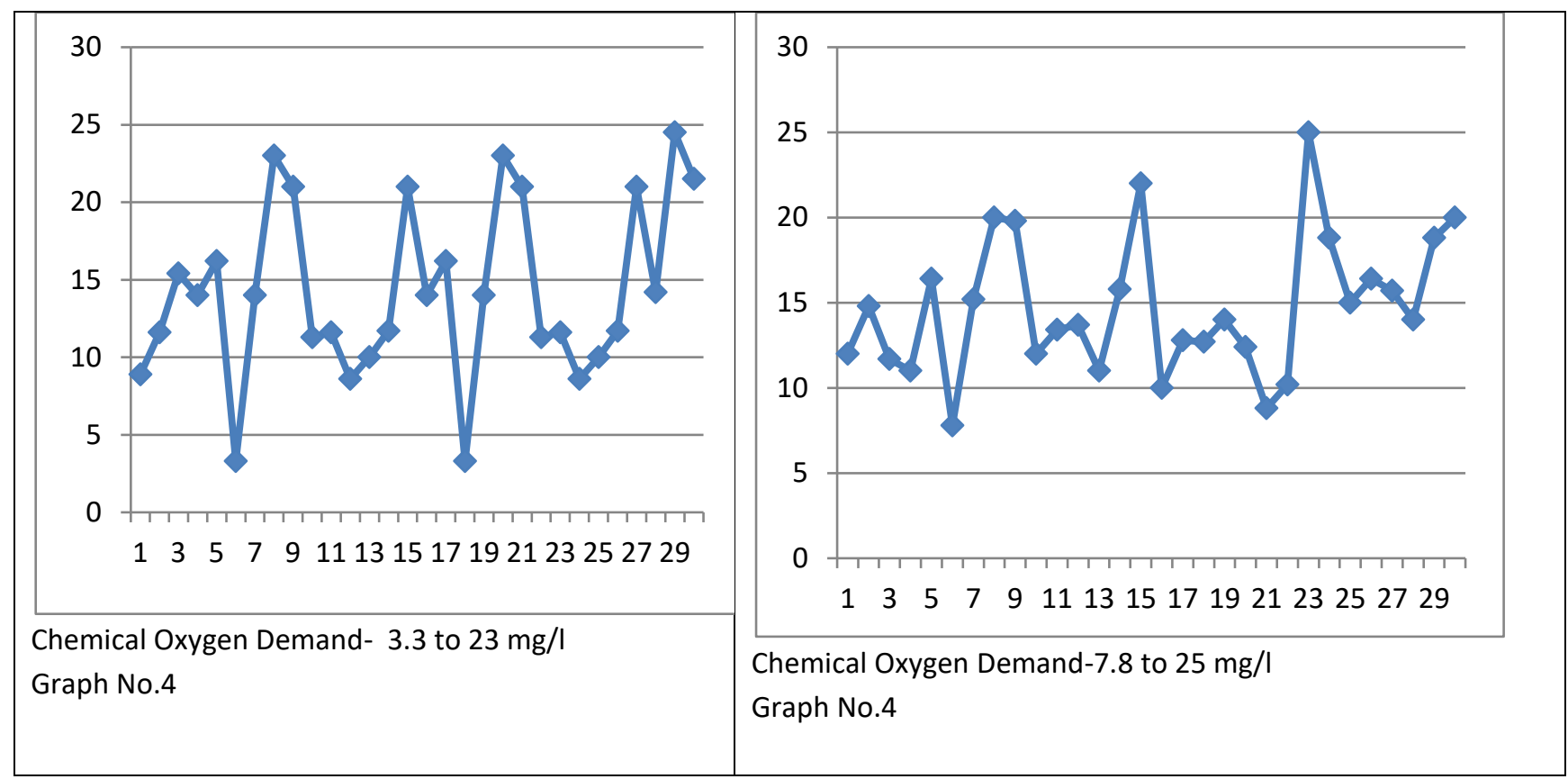

\section{CONCLUSION}

Application of water quality index technique for the overall assessment of the water body is a useful tool. A physico-chemical parameters including TDS, Total hardness, Chloride, Calcium, Magnesium, Sulphates showed variation in respective sampling points. The wells nearby 500 meter to the sugar industry showing high values for the analysis. While the values of the samples approximately on the 750-1000 meter wells within the normal range. Some higher values for electrical conductivity, total hardness and Total dissolved solids reported high during summer. This may be due to the fact that these parameters are concentrated in summer season because of volume of water is less and lower values for these parameter indicated that they were diluted in the rainy season.

To summarize the base line result of a present investigation, it clearly indicated that ground water of this area is not highly contaminated but there is indication of increase in pollutant load and it may be due to the discharge of industrial effluents into the river bed and other land sites which may get percolated into the ground and finally affected the ground water. Hence, prevention of ground water pollution due to any cause is very important. Therefore constant monitoring of water is required to prevent health hazards in the area for safe water supply and hygienic waste disposal should receive priority into these areas. The study indicated that some water sampling sites observed that the water with more chlorides, high hardness, more turbidity to affect its potability. Therefore it is necessary to check on that water in not potable, It is necessary to control the incoming Industrial waste by redesigning the infrastructure to protect the water resources from rivers and surrounding areas.

\section{REFERENCES}

1) Acosta-Martinez V., T.M. Zobeck, and Vivien Allen (2004): Soil Microbial, Chemical and Physical Properties in continuous Cotton and Integrated Crop-Livestock Systems, Am. J. Soil Sci. Soci. 68: 1875-1884.

2) American Public Health Association, American Water Works Association, Water Environment Federation (APHA AWWA \& WEF) - Standard methods for examination of water and waste water, (1975) $20^{\text {th }}$ Ed.

3) Central Board for the prevention and control of water pollution, New Delhi.

4) Chaterji, G.C., A.G. Biswas, and S. Nigyogi, (1964): Geology and groundwater resources of greater Culcutta industrial area, West Bengal. Bull. Geol. Surv. India, Sr. B. (21): 28-15.

5) Dee, A.K. (1988): Environmental chemistry wiley-quality rating of groundwater in south India, symp. (int). Development of groundwater resources, Madras, 3:1-8.

6) Jakher, $2003^{*}$-Original reference has not founded.

7) Kranti Sugar Industry Report 2007

8) Mariappan,V., M.R. Rajan, A. David Rajendran, P.P. Rabakara (2005): A Systematic Study of Water Quality Index Among the physiochemical characteristics of groundwater in and around Tanjavur Town, I.J.E.P. vol.25, no.6, June 2005, 551554. 


\section{The Ground Water Quality Analysis Agro based Industrial Area of Materwadi (Rajaramnagar) Village in Dindori Block, Dist. Nashik of Maharashtra, India}

9) Megha Rai and Shrivastava, 2006- Original reference has not founded.

10) NEERI (1981)- National Environment Engineering Research Institute,Nagpur -Research reports.

11) Pawar, N. J., S.S. Thigale and K.B. Pawar (1985): Impact of human activities on the quality of water in the Mutha Right Bank Canal, Pune city area, Trans. Inst., Ind. Geographers, 9(2): 25-33.

12) physiochemical characteristics of groundwater in and around Tanjavur Town, I.J.E.P. vol.25, no.6, June 2005, 551-554.

13) Pondhe, G.M. (2005): Impact of Agrobase Industries on the ground water quality of Sonai area district Ahmednagar, Ph.D. Thesis, Dr. B.A.M. University, Aurangabad. Pp 1-164.

14) Pondhe, G.M. (2005): Impact of Agro-base Industries on the ground water quality of Sonai area district Ahmednagar, Ph.D. Thesis, Dr. B.A.M. University, Aurangabad. Pp 1-164.

15) Raymahashay, B.C., (1986): Geochemistry of bicarbonate in river water, Geol. Soc. India, 27: 114-118.

16) Shakhare, V.B., P.B. Shakhare and A.R. Bidkar (2005): Studies on groundwater quality in Ambejogai City., J. Sci. Vol. XXXIII

17) Trivedy, R.K. and P.K. Goel (1986) : Chemical and biological methods for water pollution studies, Environ. Publ., Karad, India, $251 \mathrm{pp}$.

18) Ubale, M.B., S.B.Ubale. and D.G. Dhuley (2000): Analytical studies on groundwater quality in Aurangabad industrial area Part I, Proceeding on Environmental Issues and sustainable Development, of National Symposium held at Dr. B.A. M. University, Aurangabad, pp. 66-67.

19) Vishwanathiah, M.N., J.C.V. Sastri and U.S. Devivasingamani, (1977): Effect of industrial effluent on the downstream water sources at Belagola, Mandaya district Karnataka State. J. Mysore University Section-B, Science, 27 pp. $147-152$.

20) Wagh, N.S., M.Y.Khan, S.R.Thorat and S.B.Wagh (2000): Study of physicochemical parameters of Pharmaceutical industry at Aurangabad, M.S., India. Proceeding on Environmental Issues and Sustainable Development of National Symposium held at Dr. B.A.M. University, Aurangabad, pp. 66-67.

21) Young, Y.G., H.H. Hannal and J.J. Mayltend (1973): Nitrogen and phosphorus in the strech of Goadelpe river impoundments, Hydrobiol 43 (3) : 419-441. 